Nadwa : Jurnal Pendidikan Islam

Vol. 12, Nomor 2 Tahun 2018

Accredited by Ristekdikti based on Decree No. 51/E/KPT/2017

\title{
Learning Development Based On Multicultural In Inclusion School
}

\author{
Abdul Wahid, \\ abdulwahidilyas69@gmail.com \\ UIN Walisongo Semarang \\ DYP. Sugiharto, \\ Universitas Negeri Semarang \\ Samsudi, \\ Universitas Negeri Semarang \\ Haryono, \\ Universitas Negeri Semarang
}

\begin{abstract}
The aim of the study was to describe the development of multicultural-based inclusion learning in TK Talenta Semarang. This type of research is qualitative descriptive. The findings in this study are that first, multicultural-based inclusion learning is more emphasized in the implementation and evaluation of learning, second, multicultural values grow in students through activities in religious centers that emphasize social piety respecting differences, third: differences in institutions inclusive education is a miniature of diversity in ethnicity, race and religion.
\end{abstract}

Keywords : Learning development; Multicultural; Inclusion;

\begin{abstract}
Abstrak
Tujuan penelitian adalah untuk mendeskripsikan pengembangan pembelajaran inklusi berbasis multikultural di TK Talenta Semarang. Jenis penelitian ini adalah deskriptif kualitatif. Temuan dalam penelitian ini adalah bahwa pertama, pembelajaran inklusi berbasis multi kultural lebih ditekankan pada pelaksanaan dan evaluasi pembelajaran, kedua, Nilai-nilai multikultural tumbuh dalam pribadi siswa melalui kegiatan di sentra agama yang menekankan kesalehan sosial menghormati perbedaan, ketiga : perbedaan yang ada di lembaga pendidikan inklusi merupakan miniatur dari keragaman suku, ras dan agama.
\end{abstract}

Kata kunci: Pengembangan Pembelajaran; Multikultural; Inklusi 


\section{Introduction}

One of the central issues in today's global era is multiculturalism. When talking about a multicultural society, the key word to care for is tolerance. Tolerance comes from the intention and the spirit of respect for others with the belief that all human beings are essentially equal. Tolerance means the willingness to provide space and opportunities for others to carry out something that becomes their beliefs and opinions.1 Awareness of differences will raise questions for every human being when they know something different from someone, so that awareness needs to be planted that everyone has differences and instilled ways to respect these differences. Each person must be able to accept differences and make room for others to live according to their beliefs. 2 This concept not only allows people to carry out their own beliefs, but the possibility of mutually beneficial cooperation is open even though there are differences in each person. 3

Several previous studies have examined many aspects of multicultural education, such as the research of Su'ad (2013)4, Musadad (2013)5, Sofwan (2016)6, Slamet (2017)7. Some of these

1 Rusyan, A. Tabrani Rusyan, Membangun Disiplin Karakter Anak Bangsa, Jakarta: Pustaka Dinamika, 2013, p. 161.

2 Ilahi, Mohammad Takdir Ilahi, Pendidikan Inklusi, Yogyakarta: ArRuzz Media, 2013, p. 118.

3 Ujan, Andre Ata, dkk., Multikulturalisme: Belajar Hidup Bersama dalam Perbedaan, Jakarta: Indeks, 2011, p. 51.

4 Musadad, Akhmad Arif, Developing Multicultural Education Based Social Studies Training Model for Teacher's Professional Competencies. UNNES Semarang,. Journal of Educational Development. 1 (1). 2013.

5 Su'ad, Developing a Model of Multicultural School-Based Management in Senior High School in The Former Pati Residence. UNNES Semarang, Journal of Educational Development. 1 (2) 2013.

6 Sofwan, Maman Rachman, Samsudi, The Implementation and Development of Multiculturalism-Based Scouting Education in Junior High School. UNNES Semarang. Journal of Educational Development. 4 (1) 2016.

7 Slamet, Masrukhi, Haryono, Wasino, The Implementation of Multicultural Values in The Edocation Institution. UNNES Semarang. Journal of Educational Development. 5 (1) 2017. 
studies are research on the development of multicultural education models. The research integrates multicultural education into scouting activities in junior high school, integrating into subjects in high school, strengthening teacher professional competence and increasing the role of families, schools and communities in developing multicultural based education. This shows how important the development of multicultural based education is through educational institutions in particular, as well as families and society in general.

Multicultural based learning is meant as a form of contemporary learning in order to equip students to respect the diversity of ethnicity, race, religion, language. 8 Multiculturalbased learning can lead students to behave and have tolerant and inclusive views on the reality of a diverse society, both culture, ethnicity, race, ethnicity and religion.

This research was a field research with a descriptivequalitative approach. A qualitative approach in educational research will provide various benefits. This approach could be considered more appropriate to reveal in depth, comprehensively a variety of variables in social problems, as found in education. This approach will also open wider opportunities, without limiting hypotheses, other variables to approach the true truth.

\section{Multicultural Based Learning in Inclusion Schools}

Inclusion schools were educational institutions that try to meet the needs of joint learning in the same class for normal children and children with special needs. The process of assimilation is very possible for discriminatory attitudes and intolerance of normal children to children with special needs. Students in inclusive schools were conditioned not only to learn tolerance towards differences in religion, ethnicity, race, language, but also to learn to respect all forms of deficiencies of children with special needs. Understanding and appreciation of normal children for children with special needs was very important to be embedded in the model of inclusive education, in order to build a conducive learning situation.

8 Mahfud, Choirul, Pendidikan Multikultural. Yogyakarta: Pustaka Pelajar, 2011, p. 185. 
According to Minister of National Education Regulation Number 70 of 2009 Article 2, the purpose of inclusive education is (1) to provide opportunities for students who have physical, emotional, mental and social disabilities or have special intelligence and / or special talents to obtain quality education according to their needs and abilities, (2) realizing education that respects diversity, is not discriminatory for all students, including students with physical, emotional, mental, and social abnormalities or has intelligence potential and / or special talents.

Educational institutions and teachers as educated personnel have an important role in developing multicultural based education. In a heterogeneous condition of society, it is necessary to instill awareness of multicultural values. Multicultural awareness in the context of educational institutions is the awareness of providing educational services for people who have different needs. Some important steps related to this are; (1) building a paradigm of diversity, (2) appreciating language diversity, (3) building gender sensitivity, (4) building attitudes of social care, (5) building anti-ethnic discrimination attitudes, (6) building anti-discrimination attitudes towards differences in abilities, ( 7) build anti-age discrimination attitudes.9

Inclusive education has different dimensions than schools in general. According to Friend and Bursuck, 10 inclusive education has three dimensions, namely (1) physical integration, namely placing students with special needs in the same room as normal students, (2) social integration, namely the relationship between students with disabilities and classmates, peers, and adults must always be maintained, (3) Integration of learning, that learning for students with special needs must apply the same curriculum that is used for normal students. Of course by providing teaching and achievement targets that have been modified according to the level of ability of children with special needs.

Schools and especially teachers must play a role as role models and drivers of awareness for students to avoid

9 Suryana, Yaya dan Rusdiana, H. A., Pendidikan Multikultural, Bandung: Pustaka Setia, 2015, p. 276-280

10 Friend, Marilyn dan William D. Bursuck. (2015). Menuju Pendidikan Inklusi. Terj. Annisa Nuriowandari. Yogyakarta: Pustaka Pelajar, 2015, p. 35. 
discriminatory attitudes and behavior. To respond to the different abilities of each individual, it is necessary to inculcate mutual understanding and respect. To deal with these diverse conditions, ideally schools must provide special services, such as teachers with special abilities to handle students who have different abilities and provide special facilities.

\section{Development of Multicultural Based Learning in Talenta Kindergarten}

TK Talenta Semarang which is located at Jalan Puspowarno Tengah IX / 6 Semarang city is the only kindergarten Inclusion in the city of Semarang. This private education institution also opens a Play Group, Day-care, Primary School and Therapy Services for children with special needs. Established in 2010, TK Telenta strives to focus on developing inclusive and multicultural education. With the number of teachers and staff of 18 people, this kindergarten strives to provide inclusive education services that have not been widely carried out by other educational institutions. The heterogeneity of religion, race, ethnicity, culture was very well seen among students and teachers. Although most of them were of Javanese ethnic background, there are also some children from Sulawesi, Sumatra and not a few ethnic Chinese. More than that, as an inclusive school, the difference in physical and psychological conditions and the ability of students also varies. In 2018/2019, TK Talenta managed 4 classes consisting of 54 children, of which 25 were children with special needs. In each class there were children with special needs, with various limitations they have. Of course this was an interesting challenge for the development of multicultural based learning in this inclusive school.11

This multicultural-based education practice was not taught as a separate subject but was integrated through every subject matter, learning strategy, learning method, teaching material, learning media, as well as habituation and example. Teachers could provide examples and build linkages between themes with various forms of existing abilities, especially for children with special needs. The integration of these themes certainly couldnot

11 Buku Panduan Akademik TK Talenta Tahun Ajaran 2018/2019. 
be separated from the concept to be taught. The integration of multicultural learning could be developed through methods, teaching materials and the media used and could support children with special needs when learning. Steps were seen to foster tolerance and respect for children. Habit in the school environment could also be a way of integrating tolerance values. Habituation could be done by building friendships and active communication between children, in order to grow the attitude of accepting differences between them.

In general, multicultural based learning has been developed in Talenta Kindergarten, as well as the criteria explained by Friend and Bursuck. Learning in TK Talenta was not much different from other kindergartens. This kindergarten learning program has implemented the 2013 Curriculum with the Beyond Center and Circle Time (BCCT) approach. Through this approach, children were stimulated to actively played activities while learning in learning centers. All learning activities focus on children as "subjects of learning", while educators act more as motivators and facilitators by providing footholds.

Beyond Center And Circle Time (BCCT) Approach is a highly recommended approach in the practice of implementing early childhood education. This approach focuses on children in the learning process centered on the center of play and when children are in a circle using 4 types of scaffolding to support child development. The four steps referred to are (1) the foothold of the playing environment; (2) footing before playing; (3) footing during playing; and (4) footing after playing.12

The footing in the context of the BCCT approach is changing support that is adjusted to the development achieved by the child, which is given as a basis for achieving higher development. The footing is given before and after the child plays, done in a circular sitting setting. Another step is the environmental footing (empowering the diversity of the playing environment) and the

12 Gautama, Pedoman Peneapan Pendekatan "Beyond Centers and Cicles Time (BCCT")" (Pendekatan Sentra dan Saat Lingkaran) dalam Pendidikan Anak Usia Dini (Jakarta: Depdiknas, Dijen PLS, Direktorat Pendidikan Anak Usia Dini, 2006), p. 2-3 
foundation for each individual child (that there is no child in the same) that is carried out during the child's play.

Adopted from Florida US Creative Center for Childhood Research and Training (CCCRT), Play Center is a children's play zone or area that is equipped with a set of playgrounds that function as an environmental platform, which is needed to support children's development in 3 (three) types of play, namely (1) sensorimotor or functional play; (2) playing roles; and (3) playing development. Whereas when the Circle is a time where the teacher in this case the teacher or the tutor sits with the child in a circular position to give a foothold to the child that is done before and after playing.13 The application of the BCCT approach which is intended to improve the practice of PAUD implementation is still a lot of misguided.

In terms of planning learning according to the 2013 Curriculum TK Talenta formulates learning programs for students into the Annual Program (Prota), Semester Programs (Promes), Weekly Activity Units (SKM) and Daily Activity Units $(S K H)$. This planning was no different from general kindergarten planning. The difference is in the choice of themes. In developing the theme of learning TK Talenta was more likely to take one example of a theme but is explored in depth, which was called "Puncak Tema". For example for the theme "Plants", the teacher determines one type of plant for example "Corn". For further discussion in depth about corn, so as to cover as many aspects of corn as possible. While kindergarten is generally more likely to present the theme of this plant by introducing as many types of plants as possible, but not accompanied by in-depth study. The manager of this learning program is named after the modified 2013 curriculum.

Based on the findings of the study, in the implementation of the learning several aspects developed by TK Talenta could be described as follows:

1. Teachers in TK Talenta were required to have a different spirit and ability than other kindengarten. Taking into account the ability of different students, each class was taught by two teachers. One Master Teacher and one Shadow Teacher. The

13 Ibid., p. 4-6. 
study group at TK Talenta was a maximum of 15 children, some of whom were Children with Special Needs. The main teacher was in charge of managing learning in general, while shadow teacher was responsible for handling children with special needs in the event of a special situation called "tantrum". This Shadow Teacher had been given special skills to deal with the Tantrum situation. This particular situation or Tantrum was for example an increase in emotions, convulsions and other symptoms experienced by Children with Special Needs during learning activities. The main teacher continues to carry out the learning, while the shadow teacher focused on dealing with children with special needs who experience tantrums until they return to normal both physically and psychologically. In handling the tantrum situation the teacher provides special therapy with the term "pressing". The teacher hugs the child by giving suggestions, whispers to the ears to calm the child. The situation was considered normal if the child's heart rate has returned to normal. This treatment was still done in the classroom, so as not to be impressed that Children with Special Needs were distinguished from other normal children. This practice showed that non-discriminatory treatment remains a spirit of learning practice in TK Talenta, while providing special services.

2. The study room in TK Talenta was not equipped with a chair with the intention of giving students freedom of movement. In addition, the absence of chairs or furniture in the classroom is intended to prevent children with special needs especially from the risk of physical accidents, in the event of a special situation. In the event of a special situation for children with special needs, a special chair was prepared in the classroom, which was placed in the corner of the class, to calm or neutralize the condition of children who experience tantrums. This arrangement could support learning using the BCCT approach. The preparation of centers and circles will be more freely carried out in this way.

3. The learning method was developed by emphasizing the maximum improvement of children's skills and independence, especially for Children with Special Needs. In general, the methods developed were not much different from other 
kindergartens, such as habituation and example, demonstration, practice, simulation, tourism work and other creative activities. Treatment and learning for Children with Special Needs were not distinguished from other normal children. As much as possible the teacher would encourage Children with Special Needs to carry out their own activities and tasks in learning. The method of paired learning between normal children and Children with Special Needs was also developed to foster a sense of caring, respect and willingness to helped each other among students. This method could be said to be a form of internalization of feelings of empathy for Children with Special Needs, without separating them from association. This method was expected to further enhance the confidence of Children with Special Needs, thus increasing their independence.

4. Sources and media of learning in TK Talenta at a glance were not much different from Kindergarten in general. But in the selection of sources and learning media, managers and teachers pay attention to special interests to help children's growth and development, especially for Children with Special Needs. There was no difference when a child uses sember and this media. But for Children with Special Needs the teacher would give special attention and assistance that aims to therapy for the lack of children, especially those who experience physical disruption. Some examples of game tools such as trampolines, large balls, cursory beams were not much different from other kindergartens. But in practice, these tools were provided with the aim of therapy for Children with Special Needs with teacher supervision and guidance.

5. The Therapy Program for children with special needs was mandatory in the Talenta Kindergarten. Every Child with Special Needs must routinely undergo a Therapy program provided by the school or outside the school. This therapy program was intended as a form of special service for Children with Special Needs in learning programs. Progress in therapy was expected to also improve the ability of Children with Special Needs to study in Talenta Kindergarten. Every Monday every parent or guardian of Children with Special Needs must provide a written report on the results of the 
therapy that had been done to the Talenta Kindergarten through their respective classroom teachers. This therapeutic report would be the material for the teacher to design learning programs, determine the achievements, and the treatment that must be given to the child. This program was an effort by the school to ensure that parents or guardians of children with special needs were fully responsible and pay attention to children's development. Even schools set sanctions, if within one month the Children with Special Needs were not treated, the child could not continue his studies at Talenta Kindergarten. This program was seen as a collaborative effort by schools and parents to gave full attention and developing opportunities for children with special needs.

The evaluation phase was intended as an effort to find out the success of the learning program that has been done. The evaluation model developed in the TK Talenta generally follows the standard assessment set in accordance with the 2013 Curriculum. This evaluation refers to the Minister of Education and Culture Regulation No. 137 of 2014 concerning Standards for the Level of Child Development Achievement. This regulation classified early childhood according to age groups. In it had been determined the scope of development and the level of achievement of child development. The scope of development includes 6 aspects, namely; (1) Religious and Moral Values, (2) Motor Physical, (3) Cognitive, (4) Language, (5) Social Emotional and (6) Art.14

In general, the target of achieving the ability of children in the TK Talenta was guided by the regulation. The report card format also follows the provisions of the Education Office. In practice, the normal children of Talenta Kindergarten applied assessment according to standards, but for Children with Special Needs an assessment or evaluation was carried out by paying attention to the development of each child. For example, if for a normal child given an achievement target can write letters or numbers, then for Children with Special Needs with certain conditions it was sufficiently targeted to be able to hold the pencil

14 Peraturan Menteri Pendidikan dan Kebudayaan RI Nomor 137 tahun 2014 tentang Standar Isi Tingkat Pencapaian Perkembangan Anak. 
correctly. This was based on the consideration that the target was directed in an effort to increase children's independence.

\section{Internalization of Value in Multicultural Learning in TK Talenta}

Inclusion schools with diversity and differences in children's abilities can be a trigger for discriminatory acts. At this early age level children were not psychologically mature enough to understand and manage differences. With this condition it was feared that there will be acts of intolerance, especially from normal children to children with special needs.

Symptoms of negative attitudes and behaviors in this zero tolerance can be recognized; (a) Scapegoating is the attitude of assigning errors to certain groups of traumatic events or matters relating to social problems, (b) Bullying is the use of physical capacity that perceives themselves superior to insult others or 'revoke' rights or status others, (c) Stereotyping is to bring up the characteristics of a group with properties that are usually negative, aiming to drop. 15 Some of these negative attitudes and behaviors were possible to develop in inclusive schools such as TK Talenta. Spontaneous reactions of normal children to children with special needs might be shown in the form of non-tolerance attitudes and behavior. Of course this was a serious consideration for teachers to avoid this happening.

Practically, instilling or educating the value of tolerance to children can be done in two forms. First, educating tolerance values on certain subjects (subject matter), and second, educating the value of tolerance through and integrated in all learning programs and processes. Learning in order to educate or instill the values of tolerance is done specifically can be done with case studies through several stages. The stages that must be carried out are: (1) case narration of case; (2) identification of values; (3) literacy of norms; (4) affixation of consciousness and; (5) internalization of value. The design of this learning strategy starts from telling a story and ending with personalization of values. The story method that is presented with a variety of good

15 Mulyana, Rohmat, Case-Based Value Learning: A Challenging Issue for Teaching Religion in Indonesia. Bandung: UPI, 2005, p. 6. 
variations will be an effective method of introducing and instilling values in children.

One factor that can reduce intolerance in multicultural groups is religious teachings. Related to the value-planting strategy through stories, of course in religious teachings there will be many teaching materials in order to instill values. Planting morals and religious values in early childhood is very fundamental and determines child development in the next period. Of course learning carefully and paying attention to their level of development. At an early age where the level of thinking of children is all concrete, it is certainly a challenge for teachers or mentors. Teacher professionalism will be tested when dealing with the world of early childhood.16

Attention to behavior that was not in line with the multicultural spirit gets serious attention in TK Talenta. This is based on the high likelihood of attitudes or non-tolerant actions as explained by Mulyana. In developing moral and religious aspects through the Takwa Faith Center, TK Talenta applied the Devotional program. This activity was carried out in the morning at the beginning of class hours. In this activity students were guided and directed to pursue their respective religious teachings. For those who were Muslim, they were guided by religious teachers, as well as those who are non-Muslims. Activities carried out in the form of worship activities such as; prayer, recitation, prayer, wisdom stories, knowing God more closely. Physical activity at the Faith Taqwa center was also designed by the teacher in the form of seeing tasbih, coloring places of worship. In this activity the child was obedient to his God, a sense of love for his religion, and at the same time cultivates an attitude of respect for his friend's religion.

The center of Imtaq at TK Talenta occupied an important position for the purpose of building a spirit of mutual respect for differences. The teachers emphasized to all students to respect, love and help their friends regardless of their religious background or condition. As the strategy presented by Mulyana, the activities of this Imtaq center seem to have been in line with 
the stages set out in this value-planting strategy. In addition to these habituation activities, the full story wisdom method presented at the Faithful Taqwa center with the aim of internalizing values is also often developed by the teacher. This method is considered effective enough to suppress attitudes and intolerant actions among students in the Talenta Kindergarten.

\section{Conclusion}

TK Talenta was a National-style kindergarten, where religious, racial, ethnic, social and economic backgrounds are very heterogeneous. Multicultural-based learning practices in Talenta Kindergarten include planning, implementing and evaluating. In terms of planning learning, TK Talenta applied the 2013 Curriculum with the BCCT approach, but was modified to suit the conditions and needs of the child. In the planning stage, multicultural based learning content was not clearly stated. The values of tolerance, understanding and appreciating diversity were applied in the implementation phase and evaluation of multicultural based learning. In the implementation and evaluation of learning, teachers applied competency targets according to the 2013 Curriculum standards. However, for children with special needs, teachers applied special standards tailored to the level of development of each child. Therefore, routine therapy for Children with Special Needs is required by the school, in order to support the learning progress of Children with Special Needs. Multicultural value and spirit planting was emphasized through the Faith Taqwa center in the form of "devotion" activities as a continuous effort to instill mutual respect for differences and shortcomings.

\section{Bibliography}

Friend, Marilyn dan William D. Bursuck, Menuju Pendidikan Inklusi. Terj. Annisa Nuriowandari. Yogyakarta: Pustaka Pelajar, 2015.

Gautama, Pedoman Peneapan Pendekatan "Beyond Centers and Cicles Time (BCCT")" (Pendekatan Sentra dan Saat Lingkaran) dalam Pendidikan Anak Usia Dini, Jakarta: Depdiknas, Dijen PLS, Direktorat Pendidikan Anak Usia Dini, 2006. 
Ilahi, Mohammad Takdir, Pendidikan Inklusif, Yogyakarta: ArRuzz Media, 2013.Mahfud, Choirul. 2011. Pendidikan Multikultural. Yogyakarta: Pustaka Pelajar.

Mulyana, Rohmat, Case-Based Value Learning: A Challenging Issue for Teaching Religion in Indonesia. Bandung: UPI, 2005.

Musadad, Akhmad Arif, Developing Multicultural Education Based Social Studies Training Model for Teacher's Professional Competencies. UNNES Semarang,. Journal of Educational Development. 1 (1). 2013.

Permendiknas Nomor 70 Tahun 2009 tentang Pendidikan Inklusif bagi Peserta Didik yang Memiliki Kelainan dan Memiliki Potensi Kecerdasan dan/atau Bakat Istimewa.

Peraturan Menteri Pendidikan dan Kebudayaan RI Nomor 137 tahun 2014 tentang Standar Isi Tingkat Pencapaian Perkembangan Anak.

Rusyan, H. A. Tabrani, Membangun Disiplin Karakter Anak Bangsa, Jakarta: Pustaka Dinamika, 2013.

Slamet, Masrukhi, Haryono, Wasino, The Implementation of Multicultural Values in The Edocation Institution. UNNES Semarang. Journal of Educational Development. 5 (1) 2017. Sofwan, Maman Rachman, Samsudi, The Implementation and Development of Multiculturalism-Based Scouting Education in Junior High School. UNNES Semarang. Journal of Educational Development. 4 (1) 2016.

Su'ad, Developing a Model of Multicultural School-Based Management in Senior High School in The Former Pati Residence. UNNES Semarang, Journal of Educational Development. 1 (2) 2013.

Sujiono, Yuliani Nurani, Bambang Sujiono, Mеnu Pembelajaran Anak Usia Dini, Jakarta: Citra Pendidikan, 2005.

Suryana, Yaya, Rusdiana, H. A., Pendidikan Multikultural, Bandung: Pustaka Setia, 2015.

Ujan, Andre Ata, dkk. (2011). Multikulturalisme: Belajar Hidup Bersama dalam Perbedaan. Jakarta: Indeks. 